\title{
SCHOPENHAUER E A PESSIMISMUS-FRAGE: A INFLUÊNCIA DA FILOSOFIA SCHOPENHAUERIANA DURANTE A CONTROVÉRSIA SOBRE O PESSIMISMO NA FILOSOFIA ALEMÃ DO FINAL DO SÉCULO XIX
}

\author{
SCHOPENHAUER AND THE PESSIMISMUS-FRAGE: THE INFLUENCE OF \\ SCHOPENHAUERIAN PHILOSOPHY DURING THE CONTROVERSY ABOUT \\ PESSIMISM IN GERMAN PHILOSOPHY BY THE END OF THE 19 TH CENTURY
}

DANIEL QUARESMa FigueIRA SOARES ${ }^{1}$

Universidade de São Paulo (USP) - Brasil/Universität Mainz - Alemanha danielquaresmasoares@gmail.com

\begin{abstract}
RESUMO: A fim de celebrar o bicentenário da publicação d'O mundo como vontade $e$ representação, rememoraremos uma polêmica de grandes proporções na filosofia alemã ao final do século XIX: a Pessimismus-Frage (controvérsia sobre o pessimismo). Originada pela recepção da filosofia schopenhaueriana, essa polêmica suscitou - sobretudo após a morte de Schopenhauer - extensos debates entre os partidários do pessimismo filosófico e seus críticos. Iniciaremos descrevendo algumas características do horizonte intelectual alemão da época. A seguir, apresentaremos traços do pensamento de três representantes da chamada escola de Schopenhauer, defensores do pessimismo filosófico. Posteriormente, elencaremos algumas das principais críticas dirigidas contra Schopenhauer e seu pessimismo, oriundas sobretudo do movimento neokantiano, ora dominante na filosofia universitária alemã. Concluiremos mostrando como a Pessimismus-Frage tinha como pressuposto uma discussão acerca da natureza e dos limites da própria filosofia, ressaltando a influência (geralmente subestimada) da filosofia schopenhaueriana durante a segunda metade do século XIX na Alemanha.
\end{abstract}

PALAVRAS-CHAVE: Schopenhauer. Pessimismo. Filosofia alemã. Século XIX. Neokantismo.

ABSTRACT: To celebrate the bicentenary of The World as Will and Representation publication, we review a polemic of major proportions in German philosophy of the late 19th century: the Pessimismus-Frage (controversy about pessimism). Originated by the reception of schopenhaurian philosophy, this polemic rouse - especially after Schopenhauer's death - wide-ranging debates between supporters of philosophical pessimism and their critics. We begin by describing some characteristics of the German intellectual horizon at that time. Next, we present lines of the thinking from three representatives of the so-called Schopenhauer's school, defenders of philosophical pessimism. Subsequently, we list some of significant criticism towards Schopenhauer and his pessimism, deriving mostly from the neo-Kantian movement, currently dominant in German university philosophy. We conclude showing how the Pessimismus-Frage had as a precondition a discussion about nature and limits of philosophy itself, highlighting the influence (generally underrated) of schopenhaurian philosophy during the second half of the 19th century in Germany.

KEYWORDS: Schopenhauer. Pessimism. German philosophy. 19th century. Neo-Kantianism.

\footnotetext{
${ }^{1}$ Pesquisador pós-doutorando em filosofia na Universidade de São Paulo (USP) e na Johannes Gutenberg - Universität Mainz (bolsista DAAD).
} 
À guisa de celebração dos 200 anos da publicação do primeiro volume d' $O$ mundo como Vontade e Representação, relembraremos um debate filosófico que merece atenção na história da filosofia: a chamada Pessimismus-Frage, ${ }^{2}$ resultante da abrangente influência da filosofia schopenhaueriana no horizonte intelectual alemão durante as décadas finais do século XIX. Muito já se falou (e com razão, dada a fertilidade dos temas) sobre a influência da filosofia de Schopenhauer sobre autores determinados, como por exemplo, Nietzsche, Thomas Mann ou o primeiro Wittgenstein. Contudo, por vezes esquecemos que a penetração da filosofia schopenhaueriana atingiu diferentes campos do cenário intelectual alemão ao final do século XIX, não se restringindo apenas a influenciar determinados autores em pontos específicos de suas obras, mas também pautando temas e discussões amplas entre correntes intelectuais distintas. Por isso, neste artigo pretendemos apresentar (de modo introdutório e descritivo, sem a pretensão de reproduzir as minúcias dos argumentos, pois seria impossível abarcar em curto espaço toda a amplitude do debate) a importância da Pessimismus-Frage em seu tempo: originada pela recepção da filosofia schopenhaueriana, essa acalorada polêmica movimentou amplamente a filosofia alemã ao final do século XIX, causando repercussões em diferentes correntes de pensamento do período. Numa recente obra dedicada ao tema, um historiador da filosofia chega a dizer que a Pessimismus-Frage foi "a principal disputa filosófica na Alemanha nas últimas quatro décadas do século XIX” (BEISER, 2016, p. 8). ${ }^{3}$

Como sabemos, após amargar décadas de anonimato, o autor d'O mundo como vontade e representação chegou a presenciar ao final de sua vida o sucesso e a crescente influência de sua filosofia. Neste trabalho pretendemos mostrar como a filosofia de Schopenhauer desempenhou o papel de protagonista do debate filosófico alemão na segunda metade do século XIX. Para ressaltar esse papel,

\footnotetext{
${ }^{2}$ Como ainda não há uma tradução consolidada do nome dessa polêmica em língua portuguesa, preferimos manter a denominação alemã original para evitar mal-entendidos. Embora mesmo em língua alemã a nomenclatura possa variar - Eduard von Hartmann, por exemplo, um dos protagonistas da controvérsia, chega a usar o termo "Pessimismusstreit" no prefácio à segunda edição de Zur Geschichte und Begründung des Pessimismus [Sobre a história e fundamentação do pessimismo] (HARTMANN, 1892, p. IX) - adotamos a denominação alemã mais consagrada: Zur Pessimismus-Frage é também o título de um artigo que o próprio Hartmann dedica ao tema (HARTMANN, 1885, p. 78-120). O termo pode ser traduzido como "polêmica do pessimismo", "questão do pessimismo" ou mesmo "controvérsia sobre o pessimismo". Seja como for, o relevante é ressaltar que a noção de pessimismo, tendo então como principal referência a filosofia schopenhaueriana, era o objeto da controvérsia, como ficará claro adiante.

${ }^{3}$ Beiser inicia essa obra circunscrevendo seu tema e ao mesmo tempo procurando oferecer uma primeira tentativa de definição: "Este livro tenta explorar um território novo na história da filosofia. Seu tema é a controvérsia do pessimismo no século 19 na Alemanha, o debate sobre o valor da vida ou da existência que começou na década de 1860 com a descoberta da filosofia de Schopenhauer. Apesar de toda sua importância para seus contemporâneos, essa controvérsia foi amplamente esquecida, na Alemanha e no mundo anglófono, desde a Primeira Guerra Mundial" (BEISER, 2016, p. V). Embora concordemos que o tema mereça maior aprofundamento pela historiografia filosófica e tenha passado grande parte do século XX praticamente esquecido (eis um dos motivos de nossa escolha para a celebração do bicentenário da publicação da obra magna de Schopenhauer), devemos também observar que já há nas últimas décadas um germe de retomada dos estudos acerca da importância da recepção da filosofia schopenhaueriana no final do século XIX e da chamada escola de Schopenhauer. Além do trabalho de Beiser em língua inglesa, podemos citar também a obra Michael Pauen em língua alemã (PAUEN, 1997), a de Giuseppe Invernizzi em língua italiana (INVERNIZZI, 1997) e os relevantes estudos realizados pelo Centro Interdipartimentale di Ricerca su Arthur Schopenhauer e la sua Scuola, sediado em Lecce (ver em Referências Bibliográficas: FAZIO, 2009 e 2010; CIRACİ; FAZIO; KOßLER, 2009; VITALE, 2014).
} 
procuremos remontar brevemente esse cenário e algumas das principais correntes intelectuais que o compunham.

Paralelamente à vertente materialista (representada por nomes como Moleschott e Büchner) e à forte penetração do darwinismo, o horizonte intelectual alemão neste período possuía algumas características específicas. Os inquestionáveis avanços das ciências empíricas e a consequente exortação de seu método reverbera de maneira geral sobre a filosofia sob a forma de um descrédito em relação aos grandes sistemas idealistas (sobretudo os de Schelling e Hegel) que predominaram durante a primeira metade do século, assim como em relação ao seu método, que amiúde passara a ser caracterizado pejorativamente como especulativo. Ao mesmo tempo em que se exige da filosofia cada vez mais alguma forma de incorporação dos recentes resultados obtidos pelas ciências, disseminase uma desconfiança sobre os grandes sistemas filosóficos, comumente referidos pejorativamente como Weltanschauungen, e aos ramos desses sistemas que aparecem como os especulativos por excelência, sobretudo a metafísica e a ética. Um historiador da filosofia alemã descreve esse momento como uma "crise de identidade da filosofia" (SCHNÄDELBACH, 1983, p. 17). ${ }^{4}$ Todo esse contexto culmina num amplo domínio da filosofia acadêmica alemã pelos neokantianos durante este período. Afinal, sob o lema do retorno a Kant encontra-se tanto um manifesto repúdio aos sistemas especulativos pós-kantianos de Schelling e Hegel quanto uma concepção geral do papel da filosofia que poderia ser descrita como uma tentativa de (sob diferentes formas) reduzir a filosofia à teoria do conhecimento5. Sobretudo a partir da década de 1860, neokantianos como Kuno Fischer, Eduard Zeller, dentre outros, conseguem impor sua concepção filosófica de maneira praticamente hegemônica à filosofia acadêmica alemã. Num artigo bastante informativo em que descreve a situação da filosofia alemã em 1877, Wilhelm Wundt ressalta (valendo-se inclusive de uma tabela numérica com dados sobre os cursos universitários oferecidos pelas universidades de língua alemã) a marcante diferença entre a primeira e a segunda metade do século na filosofia acadêmica alemã: "uma completa revolução teve lugar no rumo de nossa formação filosófica" (WUNDT, 1877, p. 496). Segundo Wundt, o "declínio dos sistemas especulativos que predominaram por tanto tempo" trouxe consigo uma acentuada queda das disciplinas acadêmicas dedicadas à metafísica e à ética, ao passo que passaram a imperar aquelas que tinham por objeto a lógica e, sobretudo, a história da filosofia (WUNDT, 1877, p. 494-495). Wundt acrescenta que, de todos os cursos dedicados à metafísica, ao menos metade tratavam também de lógica, "enquanto o restante ou são proferidos por homens velhos, os últimos pilares sobreviventes dos sistemas metafísicos outrora predominantes, ou consistem em preleções que poderiam talvez ser melhor descritas como contra a metafísica" (WUNDT, 1877, p. 496; grifos do autor).

Contudo, essa hegemonia neokantiana fora estabelecida principalmente intramuros da academia filosófica: a ela opõe-se outra corrente filosófica,

\footnotetext{
${ }^{4}$ O mesmo fenômeno é descrito por KÖHNKE, 1991, p. 74.

${ }^{5}$ Segundo a descrição de Beiser, referindo-se ao neokantismo: "admitidamente, a filosofia tornouse agora uma serviçal das ciências" (BEISER, 2016, p. 20). Contemporâneo do movimento neokantiano, Wundt também se refere à "tendência, dominante em todo o movimento neokantiano, de forçar os últimos desenvolvimentos da ciência de qualquer maneira para o interior da linguagem das fórmulas kantianas" (WUNDT, 1877, p. 514). Para mais informações sobre o neokantismo em geral: KÖHNKE, 1991.
} 
caracteristicamente extra-acadêmica, que podemos denominar escola de Schopenhauer. Tal corrente dá continuidade em seu próprio tempo à oposição à filosofia acadêmica que Schopenhauer já tecera em seu escrito Sobre a filosofia universitária (SCHOPENHAUER, P I, p. 173-242). Atento a esse fenômeno em sua descrição da filosofia alemã do período, Wundt salienta que outra diferença marcante entre a filosofia alemã da primeira e segunda metade do século XIX fora a ampliação do debate filosófico para além das universidades: "o estudo filosófico atualmente é efetuado em círculos mais amplos do que anteriormente" (WUNDT, 1877, p. 498). Embora advirta para um risco de diletantismo associado a essa ampliação, Wundt a interpreta de maneira parcialmente positiva, já que ela "trouxe uma maior liberdade de expressão de opiniões do que a alcançada quando a discussão filosófica estava confinada aos limites dos nossos corpos acadêmicos" (Idem, Ibidem). Neste sentido, ratifica-se a tese de Schopenhauer em Sobre a filosofia universitária, pois Wundt adverte igualmente para o risco de "o filósofo que se sabe vigiado pelas autoridades em suas convicções políticas e religiosas" tender a "acomodar suas opiniões em alguma medida às circunstâncias externas das quais ele se vê dependente" (Idem, Ibidem). Por essa razão (e após elucidar que a filosofia extra-acadêmica, ao contrário da acadêmica, tinha como temas centrais a metafísica e a ética), Wundt caracteriza essa corrente filosófica antagônica à hegemonia acadêmica neokantiana como aquela "na qual Schopenhauer, com seu grande desprezo pela filosofia universitária, pode ser considerado a cabeça e o exemplar típico" (Idem, p. 499), concluindo que "Schopenhauer é o líder nato da filosofia não-acadêmica na Alemanha" (Idem, p. 503). Mas o que seria, afinal, essa corrente que se convencionou denominar já no final do século XIX (como fica claro a partir de textos do período ${ }^{6}$ ) escola de Schopenhauer?

A expressão não é unívoca, devendo ser bem circunscrita a fim de evitarmos mal-entendidos. Afinal, ao contrário do que o nome parece indicar num primeiro instante, alguns desses autores não se viam exatamente como participantes de uma escola coesa. Por isso, levando em conta os estudos efetuados pelo Centro Interdipartamentale di Ricerca su Arthur Schopenhauer e la sua scuola, adotaremos a distinção entre as noções de escola de Schopenhauer em sentido estrito e em sentido lato. Em seu sentido estrito, a escola de Schopenhauer é compreendida como composta por aqueles que o próprio Schopenhauer considerava seus seguidores e possuíram alguma relação pessoal com o filósofo de Danzig: fossem denominados por Schopenhauer como discípulos, apóstolos (ambos os últimos não escreviam sobre a filosofia schopenhaueriana) ou evangelistas (os que escreviam sobre seu pensamento). ${ }^{7}$ Seriam membros da escola schopenhaueriana em sentido estrito nomes como Julius Frauenstädt, Friedrich Dorguth, David Asher, dentre outros. Já a escola de Schopenhauer em sentido lato é composta por autores que não necessariamente tiveram relação direta com o filósofo (mas ocasionalmente puderam vir a ter, como é o caso de Julius Bahnsen, que pode ser considerado pertencente à escola de Schopenhauer tanto em sentido estrito quanto

\footnotetext{
${ }^{6}$ Eduard von Hartmann, por exemplo, escreveu um importante artigo denominado "A escola de Schopenhauer" [Die Schopenhauer'sche Schule] (HARTMANN, 1885, p. 38-57). Também Olga Plümacher, uma das principais seguidoras de Schopenhauer e Hartmann, faz uso da expressão já à época (PLÜMACHER, 1888, p. 4).

${ }^{7}$ Para mais informações acerca dessa caracterização da escola de Schopenhauer, ver: FAZIO, 2009. Em língua portuguesa, indicamos o recente artigo de Felipe Durante (2017).
} 
lato), mas por todos aqueles que procuraram elaborar seus pensamentos partindo da filosofia schopenhaueriana e, das mais diversas formas, transformá-la. Esse é o sentido da expressão empregado sobretudo no artigo de Hartmann: "Pode-se falar numa escola de Schopenhauer em sentido lato quando se trata de, a partir de todas as tentativas deixadas por Schopenhauer, submeter sua filosofia a uma reformulação [Umbildung]" (HARTMANN, 1885, p. 39). Considerando essa distinção, precisamos esclarecer que, no escopo de uma apresentação da Pessimismus-Frage, nossa atenção recairá particularmente sobre alguns representantes da escola de Schopenhauer em sentido lato: Philipp Mainländer, Julius Bahnsen e, principalmente, Eduard von Hartmann. Ao comparar, em linhas muito gerais, aspectos do pensamento desses filósofos, poderemos ver como cada um a seu modo procurou desenvolver seus sistemas a partir de temas centrais oriundos da filosofia schopenhaueriana, revelando semelhanças elucidativas para a nossa questão.

Como mencionamos, Bahnsen pode ser também considerado um integrante da escola de Schopenhauer em sentido estrito porque se encontrou pessoalmente com o filósofo em 1856, além de terem trocado correspondência. Contudo, sua filosofia apresenta mais que uma mera interpretação, sendo uma reformulação original da filosofia schopenhaueriana. ${ }^{8} \mathrm{O}$ essencial de seu sistema está exposto na obra Der Widerspruch im Wissen und Wesen der Welt [A contradição no saber e essência do mundo] (BAHNSEN, 1882). Autodenominado Realdialektik, o pensamento de Bahnsen procura empreender uma espécie de fusão entre uma reconfiguração do cerne da filosofia schopenhaueriana, a metafísica da vontade, e uma transformação da noção hegeliana de dialética. É importante frisar essa transformação porque Bahnsen não absorverá a dialética hegeliana em geral e, tal como Hartmann, tecerá críticas ao chamado panlogismo hegeliano. Sua Realdialektik, ao contrário da dialética hegeliana, não conceberá um momento de reconciliação entre os opostos, mas compreenderá a contradição como a única realidade. Segundo Heydorn, o pensamento de Bahnsen "enreda-se cada vez mais profundamente em oposições que se produzem infinitamente por si mesmas", resultando numa "oposição insuperável [unaufhebbar] entre tese e antítese" (HEYDORN, 1956, p. 32). Por um lado, como schopenhaueriano, essa realidade será concebida como vontade. Por outro lado, como integrante da escola de Schopenhauer em sentido lato, sua reformulação da filosofia schopenhaueriana conterá uma reelaboração da noção capital de vontade: enquanto no pensamento de Schopenhauer a vontade como princípio metafísico é concebida como una (e a pluralidade pertence apenas ao domínio da representação), Bahnsen critica o monismo schopenhaueriano (HEYDORN, 1956, p. 35) e concebe a vontade como multiplicidade (adotando uma posição que, neste aspecto específico, aproxima-se daquela assumida por Nietzsche, assim como a de Mainländer, como veremos a seguir). Sendo assim, a fusão entre uma noção de contradição real que não permite

\footnotetext{
${ }^{8}$ Embora não haja ainda muitos trabalhos dedicados ao pensamento de Bahnsen, remetemos ao artigo publicado por Heydorn no Schopenhauer-Jahrbuch, "Schopenhauer und Bahnsen" (HEYDORN, 1956, p. 32-41), e aos capítulos dedicados ao filósofo nos livros de Invernizzi (1994, p. 206-262) e Beiser (2016, p. 229-284). Além disso, cabe mencionar o julgamento que Hartmann faz da filosofia de Bahnsen em "A escola de Schopenhauer", onde conclui - apesar de algumas críticas pontuais - que esse fora "o mais original e significativo talento que a escola de Schopenhauer produziu” (HARTMANN, 1885, p. 45). Mesmo havendo pouco material disponível em português sobre o pensamento de Bahnsen, remetemos também ao recente artigo publicado por Flamarion Ramos sobre o filósofo (RAMOS, 2015, p. 111-121).
} 
qualquer reconciliação e uma assunção da multiplicidade da vontade culmina na radicalização daquele caráter autocontraditório e irracional do querer já reconhecido por Schopenhauer. Em vez de uma vontade una, em Bahnsen "a própria concepção da vontade é a de algo contraditório, alógico, que consiste em querer e não querer ao mesmo tempo. A individualidade é compreendida como a expressão dessa contradição" (RAMOS, 2015, p. 115). Com isso, Bahnsen avança em direção a um pessimismo mais radical em relação ao de seu mestre: sendo a realidade apenas a autocontradição que vontades individuais trazem consigo, exclui-se qualquer possibilidade de redenção ou negação da vontade, rejeitando o aspecto soteriológico ainda presente na filosofia schopenhaueriana. Nas palavras do filósofo: "Assim dispõe [...] o juízo conclusivo da Realdialektik: "Nada se alcança". E arremata com a "confirmação do dogma fundamental de um pessimismo consequente que, enquanto tal, deve proclamar a absoluta ausência de salvação" (BAHNSEN, 1882, p. 482; grifos nossos).

Outro schopenhaueriano em sentido lato, Mainländer comunga de algumas das características do pensamento de Bahnsen: partindo da noção central da filosofia schopenhaueriana, a vontade, ele a reinterpreta e fornece sua própria versão de uma filosofia pessimista9 . O núcleo de seu pensamento foi publicado em sua obra principal: Die Philosophie der Erlösung [A filosofia da redenção] (MAINLÄNDER, 1879). Tal como Bahnsen, Mainländer adota uma concepção pluralista da vontade. Porém, a filosofia de Mainländer está centrada numa curiosa narrativa metafísica que podemos denominar suicida. A vontade de vida schopenhaueriana é transformada em vontade de morte. Essa é expressa pela vontade de um Deus que rompe com sua unidade primordial, anterior ao mundo, e decide pela própria morte. Essa morte origina um mundo condenado à multiplicidade e à vontade de morte individual de cada ser, tendo como complemento a concepção físico-cosmológica de um enfraquecimento progressivo e inexorável das forças mundanas em geral. Portanto, o mundo é concebido como a multiplicidade de vontades de morte que, numa espécie de guerra de todos contra todos, determina o enfraquecimento universal das forças e caminha inabalavelmente para o não-ser, o nada. Segundo Ramos: "Mainländer reinterpreta e radicaliza o pessimismo de Schopenhauer em uma 'metafísica da entropia', e interpreta toda a história do mundo como uma descontínua, mas inevitável decadência" (RAMOS, 2007, p. 41). Eis por que Mainländer é um defensor da castidade e do suicídio, atitudes que seriam adotadas pelos indivíduos conhecedores da essência metafísica do mundo como "meios de realizar completamente e conscientemente aquela finalidade, o nada absoluto para o qual no fim das contas o mundo inevitavelmente aponta" (Idem, p. 42). Difícil não perceber que essa Weltanschauung suicida (e, neste aspecto, questionável em relação à sua fidelidade ao pensamento schopenhaueriano) ajuda a abrir espaço para críticas generalizadoras que pretendem deslegitimar os sistemas filosóficos derivados da filosofia schopenhaueriana. Isso pode ser observado na crítica de Wundt, para quem $A$ filosofia da redenção é um "espécime exagerado do tipo de especulação fantástica, guiada mais pelo sentimento e temperamento do que pelo método científico, que reina em nossa filosofia não-acadêmica" (WUNDT, 1877, p.

\footnotetext{
9 Para apresentações mais detalhadas da filosofia de Mainländer recomendamos os capítulos de Invernizzi (1994, pp. 263-312) e Beiser (2016, pp. 201-228) dedicados ao filósofo, assim como o artigo de Flamarion Ramos (2007, p. 35-50).
} 
510). A título de curiosidade, lembremos que Mainländer cometeu suicidou ao receber o primeiro exemplar de sua obra principal, oferecendo-se como exemplo radical de seu pensamento.

Já a Philosophie des Unbewussten [Filosofia do Inconsciente], publicada por Eduard von Hartmann no final de 1868 (com data de 1869), desempenhou um papel sobremodo importante para o desenvolvimento da Pessimismus-Frage. Embora hoje praticamente esquecido, Hartmann foi indubitavelmente $\mathrm{O}$ schopenhaueriano em sentido lato mais debatido e conhecido de seu tempo, sendo mesmo um dos pensadores mais influentes ao final do século XIX na Alemanha ${ }^{10}$. Vejamos em linhas gerais (focando apenas nos elementos relevantes para uma apresentação da Pessimismus-Frage) alguns traços centrais do sistema hartmanniano.

Assim como Bahnsen e Mainländer, Hartmann também parte da noção central da filosofia de Schopenhauer: a vontade. Mais uma vez, essa noção passará por uma transformação na obra hartmanniana. Contudo, Hartmann não adota uma concepção pluralista da vontade. Sua filosofia mantém-se fiel ao monismo, mas um monismo diferente daquele concebido por Schopenhauer. Segundo o autor da Filosofia do Inconsciente, um dos pecados principais do pensamento schopenhaueriano foi conceber um "monismo abstrato" (HARTMANN, 1885, p. 27). Hartmann, ao contrário, diz-se defensor de um monismo concreto. Esse poderia surgir somente a partir de uma reformulação da noção schopenhaueriana de vontade. Essa Umbildung (tal como denominada por Hartmann) do núcleo do pensamento schopenhaueriano é apresentada, por exemplo, no capítulo A IV da Filosofia do Inconsciente ${ }^{11}$ (HARTMANN, 1869, p. 83-88). Julgando tirar consequências inerentes à noção de vontade, Hartmann argumenta que Schopenhauer recaiu num monismo abstrato ao conceber o querer como cego, indeterminado. Para Hartmann, seria impossível um mero ato de querer que não queira algo: todo querer traria necessariamente consigo o vínculo a um objeto que lhe confere seu conteúdo ideal, uma finalidade. Ou seja, o querer só pode ser um querer de algo. Essa finalidade, por sua vez, deve ser uma representação (noção que Hartmann por vezes também denomina ideia, reconfigurando também o sentido que essa noção possui no sistema schopenhaueriano $)^{12}$. Portanto, segundo Hartmann, Schopenhauer errara ao não perceber que todo querer está necessariamente vinculado a uma representação. Isso significa também que a representação não poderia continuar a ser um "produto secundário da vontade (como em Schopenhauer)” (HARTMANN, 1885, p. 51). A partir dessa reformulação, Hartmann construirá os alicerces de seu sistema.

10 Wundt refere-se a Hartmann como "o mais destacado representante [da filosofia de Schopenhauer] no presente", bem como "o primeiro que procurou introduzir sérias modificações no sistema de Schopenhauer" (WUNDT, 1877, p. 505). Para uma apresentação detalhada da filosofia de Hartmann, ver: WOLF, 2006, e VITALE, 2014.

${ }^{11}$ Outro texto crucial para compreender o que Hartmann tem em mente com essa Umbildung é um artigo denominado "Ueber die nothwendige Umbildung der Schopenhauerschen Philosophie aus ihrem Grundprincip heraus" [Sobre a reformulação necessária da filosofia schopenhaueriana a partir de seu princípio fundamental] (HARTMANN, 1868/1869, pp. 457-469), também conhecido como o Schopenhauer-Aufsatz.

12 Essa reconfiguração fica clara sobretudo a partir da leitura do Schopenhauer-Aufsatz (HARTMANN, 1868/1869). 
Já que Hartmann admite que Schopenhauer teve o mérito de reconhecer o caráter inconsciente da vontade, e já que agora todo querer é concebido como vinculado a uma representação, disso resulta que não há apenas vontade inconsciente, mas também representação inconsciente: "uma vontade inconsciente seria uma vontade com representação inconsciente como conteúdo" (HARTMANN, 1869, p. 88: "grifos do autor"). A noção de representação inconsciente talvez seja a grande inovação do sistema hartmanniano em relação ao pensamento de Schopenhauer (WOLF, 2006, p. 99). Essa reconfiguração fundamenta o que Hartmann denominará monismo concreto: vontade inconsciente e representação inconsciente serão os dois atributos de uma substância única denominada Inconsciente [Unbewusste]. Essa substância, que chega a ser denominada Espírito absoluto $^{13}$, é o núcleo metafísico da Weltanschauung hartmanniana. O percurso da Filosofia do Inconsciente será uma tentativa de demonstrar como o mundo é constituído por esse princípio único, a partir da união entre vontade inconsciente e representação inconsciente. Hartmann aplicará essa fórmula metafísica tanto à análise de processos fisiológicos (procurando atender a exigência de seu tempo de unir filosofia especulativa e método científico indutivo, como fica claro a partir do subtítulo da primeira edição da Filosofia do Inconsciente: "Resultados especulativos conforme o método indutivo das ciências naturais") quanto a questões como a linguagem e a história. Afinal, a reformulação da noção de vontade permite a Hartmann a atribuição (proibida por Schopenhauer, como sabemos) de uma finalidade à natureza e à história. Tanto a identificação do princípio metafísico de sua filosofia ao Espírito quanto a inclusão de um conteúdo ideal no cerne da noção de vontade são facetas do peculiar projeto hartmanniano (segundo ele, prenunciado pela filosofia do último Schelling) de elaborar uma síntese entre as filosofias de Schopenhauer e Hegel.

Isso transparece sobretudo na filosofia da história apresentada ao final da Filosofia do Inconsciente. Estando a vontade agora vinculada a uma finalidade, o Inconsciente é apresentado como o fio condutor de uma concepção teleológica da história. Hartmann especula que o "fim último" [Endzweck] (HARTMANN, 1869, p. 628) da história não poderia ser outro senão "o maior estado de felicidade alcançável, a ausência de dor" [Schmerzlosigkeit] (HARTMANN, 1869, p. 632-633; grifos do autor). Afinal, e agora fiel ao pensamento schopenhaueriano, a vontade é concebida por Hartmann como inerentemente insatisfeita, inevitavelmente frustrada. Por isso, em vez de se aproximar de seu fim último, o desenvolvimento histórico traz consigo cada vez mais sofrimento e insatisfação da vontade. Neste ponto, a narrativa hartmanniana recorre a um elemento familiar à tradição hegeliana: por meio de uma espécie de astúcia do Inconsciente, surge a consciência, concebida como a representação que consegue se emancipar do jugo da vontade. E será justamente o desenvolvimento da consciência, descrito como o "fim próximo" [nächste Zweck] (HARTMANN, 1869, p. 630: grifos do autor), que guiará o percurso do processo histórico, denominado Weltprocess [Processo-domundo] (HARTMANN, 1869, p. 630). Diferentemente da filosofia hegeliana, porém, o desenvolvimento da consciência para Hartmann terá o papel de desmascarar progressivamente os estágios de ilusão atravessados pela humanidade enquanto

\footnotetext{
${ }^{13}$ Contrariando a reprimenda schopenhaueriana em relação ao uso desses termos, Hartmann chega a usar as expressões "substância absoluta", "sujeito absoluto" e "Espírito absoluto" (HARTMANN, 1885 , p. 51) para se referir ao Inconsciente.
} 
julgava ser capaz de alcançar a satisfação da vontade: o primeiro estágio, correspondente à antiguidade, seria aquele que prometia a felicidade nesta vida mundana; o segundo estágio, correspondente à era cristã, trazia a promessa de felicidade num além-mundo; por último, o atual estágio, no qual a promessa da satisfação consiste no progresso da ciência, da técnica, das artes, em suma, da civilização. Em todos esses estágios a consciência se depara com aquilo que Hartmann denomina um "balanço eudemonista" (HARTMANN, 1885, p. 91-102) negativo: isto é, a conclusão de que a soma do desprazer é maior que a soma do prazer na existência em geral. Assim, essa curiosa mistura entre elementos da filosofia da história hegeliana e o núcleo herdado da metafísica de Schopenhauer acaba por ratificar a tese schopenhaueriana pessimista por excelência: o não-ser é preferível ao ser. ${ }^{14}$

O próximo passo da narrativa é também seu desfecho pessimista. O momento no qual a consciência finalmente consegue convencer a humanidade de que esta vida está fadada a um balanço eudemonista negativo será o momento no qual a decisão fundamental poderá ser tomada: a negação coletiva da vontade, a escolha pelo não-ser em detrimento do ser, a ação de "arremessar o querer no nada, com isso findando o processo e o mundo" (HARTMANN, 1869, p. 643; grifos do autor). Embora Hartmann critique a noção schopenhaueriana de negação individual da vontade por suas "consequências ascéticas quietistas" (HARTMANN, 1885, p. 34), é quase inevitável constatar que a narrativa metafísico-teleológica hartmanniana traz consigo, sobretudo nessa concepção da negação coletiva da vontade pela humanidade, certo caráter fantasioso ${ }^{15}$. E, como vimos em Mainländer, tal caráter certamente abre o flanco para críticas à escola de Schopenhauer.

Após essa apresentação panorâmica dos sistemas elaborados por três integrantes da escola de Schopenhauer, podemos perceber uma determinada comunidade entre eles: cada um a seu modo (e algumas vezes tomando posições contrárias em relação a Schopenhauer em pontos específicos, mas sempre partindo do horizonte temático schopenhaueriano), esses três filósofos buscaram efetuar uma reformulação da noção de vontade, que permaneceu no núcleo de seus sistemas metafísicos. Além disso, e novamente cada um a seu modo, os três oferecem sua própria versão de uma filosofia pessimista, mas sem nunca abandonar o lema schopenhaueriano fundamental: a tese de que o não-ser é preferível ao ser ${ }^{16}$. Por isso, é importante perceber que, por mais que esses pensadores reelaborassem algumas posições da filosofia schopenhaeuriana, não é impreciso reuni-los num conjunto denominado escola de Schopenhauer quando

\footnotetext{
${ }^{14}$ Segundo Beiser: "Quaisquer que sejam as diferenças precisas entre Hartmann e Schopenhauer, deve-se dizer que os esforços de Hartmann para assumir uma distância entre si e Schopenhauer eram mais táticos do que verazes. O que é mais arrebatador na primeira e principal exposição de seu pessimismo - capítulos C XI-XIII [...] da Philosophie des Unbewussten - é sua simpatia e afinidade com Schopenhauer" (BEISER, 2016, p. 153).

${ }_{15}$ Pauen (1997, p. 124) e Beiser (2016, p. 156) alertam para esse aspecto fantasioso da teoria da redenção hartmanniana.

${ }_{16}$ Outro traço em comum entre Bahnsen, Mainländer e Hartmann, ajudando a cristalizar aquela imagem da escola de Schopenhauer como antípoda da filosofia universitária, é a assunção de uma postura alheia à filosofia acadêmica: nenhum deles foi professor universitário. Hartmann, que chegou a ser convidado para ocupar cátedras mas sempre recusou (BEISER, 2016, p. 124), mantinha até mesmo uma postura hostil à filosofia universitária, a qual denominava pejorativamente "Zunftphilosophie" [filosofia corporativa] (HARTMANN, 1880, p. V).
} 
se considera que suas filosofias orbitam em torno da noção central (a vontade) e do pessimismo trazidos pelo sistema schopenhaueriano. E foi justamente o pessimismo o objeto da polêmica que apresentamos neste trabalho. Afinal, é fato que o pessimismo tornou-se uma moda na Alemanha nas últimas décadas do século XIX, uma espécie de estado de espírito oficial: isso é atestado tanto por relatos de intelectuais da época ${ }^{17}$ quanto por historiadores da filosofia em obras recentes. ${ }^{18}$

Não recorreremos aqui à tentativa de explicar a eclosão dessa voga pessimista a partir de razões histórico-políticas. Essa tentativa já fora realizada à época, por exemplo, pelos neokantianos Kuno Fischer e Bona Meyer, ${ }^{19}$ e posteriormente por Georg Lukács: ${ }^{20}$ esses pensadores atribuíram a erupção do pessimismo ao fracasso das ambições libertárias contidas nas revoltas de 1848. Dessa forma, tinham em comum a tentativa de caracterizar o pessimismo como uma ideologia reacionária e eram críticos da filosofia schopenhaueriana. Por outro lado, alguns historiadores da filosofia contestam essa tese que atribui uma origem histórico-política à difusão do pessimismo schopenhaueriano. ${ }^{21}$ Devido ao escopo deste trabalho, procuraremos nos restringir ao âmbito filosófico da questão, mostrando como esse Zeitgeist pessimista na Alemanha do final do século XIX relaciona-se diretamente à recepção do pensamento de Schopenhauer e à concepção de filosofia nele contido.

É interessante lembrar que o próprio Schopenhauer não privilegiara caracterizar sua filosofia com o adjetivo pessimista. Segundo Cartwright, pessimismo foi um termo "que o filósofo nunca utilizou para descrever sua filosofia em nenhum dos livros que preparou para a publicação" (CARTWRIGHT, 2010, p. 534). Fazio ratifica essa constatação, acrescentando que Schopenhauer só se referiu à sua filosofia mediante o termo pessimismo uma única vez, num fragmento póstumo (FAZIO, 2010, p. 161). Hans Stäglich, num artigo publicado no Schopenhauer-Jahrbuch, procura traçar uma história do conceito de pessimismo. O autor afirma que, embora o termo já aparecesse nos meios eruditos ao final do

${ }^{17}$ Wundt declara que "a filosofia pessimista combinava com um estado de sentimento amplamente difundido" (WUNDT, 1877, p. 505). Mesmo um dos mais ilustres neokantianos da época e combatente do pessimismo, Windelband, relata em 1876 que "em nosso tempo o pessimismo ocupa um lugar amplo e cada vez mais amplo [...] deve-se considerá-lo como um fato e com ele argumentar. O pessimismo é, indubitavelmente, uma das mais modas mais difundidas, ao menos dentro das fronteiras da vida cultural alemã" (WINDELBAND, 1924, p. 218).

${ }^{18}$ Beiser afirma que o pessimismo tornou-se naquelas décadas "o espírito da época, o Zeitgeist" (BEISER, 2016, p. 1).

19 Segundo Kuno Fischer: "A primeira metade de nosso século terminou com uma revolução e revoltas populares que falharam diante do poder do ordenamento legal, das forças de resistência do status quo e, finalmente, de sua própria irracionalidade; a segunda metade começou com uma reação geral e o sentimento predominante de que as ideias de liberdade e sua literatura fracassaram [...] Para a proteção da ordem restabelecida foram tomadas nos anos 50 uma série de medidas reacionárias [...] Automaticamente, surgiu a tendência a uma percepção pessimista, segundo a qual nenhum outro filósofo é ou poderia se tornar o filósofo notório da época senão Schopenhauer" (FISCHER, 1898, p. 97). Na mesma linha, Bona Meyer procura explicar do seguinte modo a eclosão da voga pessimista na Alemanha: "Quando Schopenhauer pensou e escreveu seu sistema no ano de 1818, a época não estava receptiva para seu pessimismo e, por isso, o solitário filósofo passou quase despercebido. A receptividade data apenas dos anos quarenta e seguintes. Nosso povo estava à época, devido às lutas de libertação, ainda cheio de esperança e ambição [...] Seguiu-se o período em que desapareceu em nosso povo essa confiança no futuro" (BONA MEYER, 1872b, p. 24).

${ }^{20}$ Lukács descreve Schopenhauer como o "filósofo da reação burguesa após 1848" (LUKÁCS, 1974, p. 15-16).

${ }^{21}$ Ver, por exemplo, STÄGLICH, 1951-1952, p. 28, e KÖHNKE, 1991, p. 73-74. 
século XVIII, ele não aparece em 1818 no primeiro volume d’ $O$ mundo como vontade e representação e tampouco nas resenhas e referências contemporâneas: "neste período o conceito não era usual na terminologia filosófica" (STÄGLICH, 1951-1952, p. 27). Ainda conforme Stäglich, apenas em meados da década de 1840 o termo começou a ser utilizado por integrantes do nascente círculo de discípulos de Schopenhauer (como Dorguth, por exemplo), e apenas em 1878 a Academia de Ciências de Paris reconheceu o termo pessimismo, 116 anos após ter reconhecido "otimismo" (Idem, p. 27-28). Assim, mesmo que o uso do termo não fosse usual para o próprio Schopenhauer, cremos ser essa uma questão meramente nominal: tanto porque, como afirma Cartwright, "ele [Schopenhauer] não fazia objeção a ser denominado um pessimista" (CARTWRIGHT, 2010, p. 4), ${ }^{22}$ quanto porque o mais importante para uma abordagem filosófica é o que se compreende pelo termo pessimismo e, consequentemente, se essa compreensão é correta para designar a filosofia schopenhaueriana. Neste sentido, podemos afirmar que (malgrado as diversas ramificações e reconfigurações assumidas) há uma compreensão comum entre os seguidores de Schopenhauer deste período acerca do significado do termo. Tal compreensão é bem expressa, por exemplo, por Plümacher. A autora dedica a Introdução de sua obra Der Pessimismus in Vergangenheit und Gegenwart [O pessimismo no passado e presente] a uma tentativa de estabelecer o significado do "moderno pessimismo filosófico, tal como foi primeiramente apresentado por Arthur Schopenhauer como membro inseparável, orgânico de um sistema filosófico fechado" (PLÜMACHER, 1888, p. 1) e que, "embora com modificações essenciais, mas igualmente ligado a Schopenhauer", tinha como representantes Eduard von Hartmann, Bahnsen, Mainländer, "dentre outros" (Idem, p. 6) ${ }^{23}$. Segundo Plümacher, a seguinte tese define o pessimismo filosófico moderno: "o não-ser do mundo seria melhor do que seu ser" (Idem, p. 1; grifos do autor). Por essa definição, a filosofia schopenhaueriana pode sem dúvida ser descrita como pessimista. Além disso, para as gerações que o sucederam e para sua escola, Schopenhauer ocupou não apenas o papel de principal representante, mas também o de fundador do pessimismo filosófico. Autores do final do século XIX e historiadores da filosofia atestam esse

${ }^{22}$ Beiser compartilha posição semelhante: "Embora Schopenhauer era, e ainda é, associado ao pessimismo, é digno de nota que ele não descreva sua filosofia como tal. 'Pessimismo' era o termo usado por seus contemporâneos e sucessores. Entretanto, é acurado e inofensivamente anacrônico atribuir esse termo a ele. Afinal, Schopenhauer não apenas expressamente repudiou o 'otimismo', que ele considerava como a antítese de sua própria filosofia, como também teve uma atitude decididamente negativa face à vida. Não temos nenhuma palavra melhor que 'pessimismo' para aquela antítese ou para aquela atitude" (BEISER, 2016, p. 45).

${ }_{23}$ Mais à frente mostraremos como os principais opositores do pessimismo filosófico foram os neokantianos. Em contrapartida, devemos mencionar que só é possível falar numa PessimismusFrage, isto é, numa controvérsia, porque o pessimismo filosófico contava com diversos defensores após a morte de Schopenhauer. Tais defensores se identificavam como pertencentes a um movimento filosófico bem determinado (definido por Plümacher como "pessimismo filosófico moderno", tendo por característica a fundamentação da tese pessimista central a partir de um "sistema filosófico fechado", ou seja, uma Weltanschauung pessimista), cujo fundador era Schopenhauer, e publicaram obras que alimentaram a controvérsia, procurando ao mesmo tempo reforçar a posição pessimista e refutar as críticas direcionadas ao pessimismo filosófico. Além dos três representantes da escola de Schopenhauer já mencionados e de Plümacher, outra importante defensora do pessimismo filosófico foi Agnes Taubert: primeira mulher de Hartmann e cuja obra Der pessimismus und seine Gegner [O pessimismo e seus adversários] (TAUBERT, 1873), marcada pelo tom combativo, foi importante para a difusão da Pessimismus-Frage. Outros partidários do pessimismo filosófico foram, por exemplo, Edmund Pfeiderer (PFEIDERER, 1875) e Ludwig von Golther (GOLTHER, 1878). 
papel. Plümacher afirma que o pessimismo fundado por Schopenhauer "é uma nova ideia no interior da filosofia ocidental" (Idem, Ibidem). Wundt declara ainda que foi "simplesmente seu pessimismo" (e não qualquer outro aspecto do sistema) o que tornou a filosofia de Schopenhauer tão popular à época (WUNDT, 1877, p. 504). Invernizzi assevera que "o tema do pessimismo faz seu ingresso no debate filosófico com a obra de Arthur Schopenhauer" (INVERNIZZI, 1994, p. 19). Beiser é igualmente incisivo: "A prevalência do pessimismo na Alemanha após a década de 1860 foi devida principalmente à influência de um homem: Arthur Schopenhauer". Segundo o autor, Schopenhauer "fez do pessimismo uma filosofia sistemática e o transformou, de uma atitude pessoal, numa metafísica e visão de mundo" (BEISER, 2016, p. 13).

Para uma reconstituição histórica fiel da Pessimismus-Frage, é importante ainda lembrar que, se o pessimismo schopenhaueriano acendeu a chama e forneceu o contexto para o surgimento de uma controvérsia acerca do pessimismo na Alemanha do final do século XIX, o grande e imediato sucesso alcançado pela Filosofia do Inconsciente ${ }^{24}$ no final da década de 1860 atuou como um combustível para o alastramento da controvérsia. ${ }^{25}$ Afinal, Hartmann era então considerado por muitos o continuador oficial do pessimismo schopenhaueriano. ${ }^{26}$ Independentemente da legitimidade filosófica desse juízo (que pode e deve ser questionada, mas não pertence ao escopo deste trabalho), historicamente é fato que, por um lado, muitos de seus contemporâneos viam no sistema hartmanniano um aprimoramento da filosofia schopenhaueriana $;{ }^{27} \mathrm{em}$ contrapartida, outros schopenhauerianos consideravam a filosofia de Hartmann uma deturpação do pessimismo. ${ }^{28}$ Além disso, certos traços do sistema hartmanniano (como sua peculiar versão do pessimismo, que culmina numa escatologia entremeada por um tom fantasista, a reivindicação de um fundamento científico para o pessimismo ou a insistência na justificação do pessimismo a partir de um balanço eudemonista) facilitaram em larga medida o trabalho dos críticos à voga pessimista crescente: atacar a versão hartmanniana parecia a via mais fácil para procurar deslegitimar o pessimismo em geral, e até mesmo toda a filosofia schopenhaueriana, como se fossem interdependentes.

O próprio Hartmann dera ensejo a essa vinculação. Embora relutasse em aceitar o papel de mero continuador do "schopenhauerianismo" e procurasse salientar também as diferenças entre seu sistema e o de Schopenhauer (HARTMANN, 1885, p. 25), no prefácio à sétima edição da Filosofia do Inconsciente

\footnotetext{
${ }^{24}$ Wundt chega a afirmar que "desde a invenção da imprensa, nenhuma obra filosófica de tamanha dimensão teve tanto sucesso na Alemanha como a Philosophie des Unbewussten" (WUNDT, 1877, p. 505).

${ }^{25}$ Sobre isso, consultar PAUEN, 1997, p. 122, e INVERNIZZI, 1994, p. 121.

${ }^{26}$ Isso transparece em diversos textos do período, tanto de críticos quanto de simpatizantes da obra de Hartmann. Um historiador da filosofia inglês, por exemplo, numa obra dedicada à história do pessimismo, confere a Hartmann um completo protagonismo dentre os "sucessores" de Schopenhauer (SULLY, 1877, p. 100ss).

${ }^{27}$ Plümacher afirma que Hartmann era o "mais extraordinário representante no presente" do "moderno pessimismo filosófico" criado por Schopenhauer (PLÜMACHER, 1888, p. 1). Até mesmo um correspondente direto de Schopenhauer, David Asher, tece rasgados elogios à Filosofia da Inconsciente numa resenha dedicada à obra (ASHER, 1869, p. 2278).

${ }^{28}$ É o caso de Bahnsen, que defende os princípios da filosofia schopenhaueriana contra a versão hartmanniana (BAHNSEN, 1872). Lembremos também das críticas direcionadas a Hartmann pelo jovem Nietzsche, sobretudo na seção 9 da Segunda Consideração Extemporânea (NIETZSCHE, 1999, Band I, p. 311-324).
} 
ele atribui o enorme sucesso dessa obra à consolidada penetração da filosofia schopenhaueriana nos círculos cultivados alemães da época. Segundo Hartmann, a Filosofia do Inconsciente encontrou "tantos calorosos amigos" porque a difusão prévia da "filosofia de Schopenhauer havia preparado o terreno para sua compreensão" (HARTMANN, 1876, p. VII). Com isso, Hartmann legitima o vínculo entre o sucesso imediato de sua obra e um contexto maior de recepção da filosofia schopenhaueriana na Alemanha daquele período. Alastrado o incêndio pessimista, a partir do final da década de 1860 os ataques à filosofia schopenhaueriana e seu pessimismo viriam de diversas correntes intelectuais: até mesmo o eminente marxista Karl Kautsky lançara mão da pena para combater esse inimigo. ${ }^{29}$

Mas, indubitavelmente, os neokantianos foram os mais ferrenhos críticos do pessimismo schopenhaueriano. Beiser chega a afirmar que houve uma "campanha neokantiana contra o pessimismo" (BEISER, 2016, p. 165), já que os "neokantianos tornaram-se virtualmente obcecados pelo 'filósofo rei de Frankfurt"' (Idem, p. 21). De fato, analisando os textos do período, constatamos que praticamente todos os principais neokantianos participaram da Pessimismus-Frage, sempre assumindo posições críticas em relação a Schopenhauer e ao pessimismo. Tais críticas abordavam diversos aspectos da questão. Elenquemos algumas das principais.

Num texto publicado originalmente em 1876 e intitulado "Pessimismo e ciência", Windelband procura analisar a característica central do pessimismo filosófico e conclui que "a mais perigosa forma" do "modismo pessimista" consiste na pretensão de atribuir a seu enunciado nuclear ("o mundo é mau e seria melhor se ele não existisse") o estatuto de verdade científica e "demonstrá-lo filosoficamente" (WINDELBAND, 1924, p. 219-224). Segundo o neokantiano, o pessimismo (assim como seu antagonista filosófico, o otimismo) consiste apenas na generalização de estados de humor [Stimmungen] subjetivos, "disposições psicológicas" que tentam se impor como "verdade objetiva", transformando "uma atitude generalizante numa Weltanschauung" (WINDELBAND, 1924, p. 221-223). O essencial do pessimismo estaria nessa "arbitrariedade" subjetiva, pois um juízo sobre o valor do mundo só seria possível sob a condição de que, primeiramente, "o universo em geral tenha um propósito ou uma determinação e, em segundo lugar, que nós possamos conhecê-los com certeza" (WINDELBAND, 1924, p. 229230). Contudo, completa Windelband, "a ciência humana nada sabe e nada pode saber" sobre "um propósito que constitua a determinação do universo e forneça o critério para seu julgamento" (WINDELBAND, 1924, p. 231). Baseado nisso, o neokantiano conclui pela "completa impossibilidade de um tal julgamento" (WINDELBAND, 1924, p. 227). Assim, ao insistir na impossibilidade de sua fundamentação científica, Windelband relega o pessimismo a uma mera

\footnotetext{
${ }^{29}$ Num texto publicado em 1888 (KAUTSKY, 1888, p. 66-78 e 97-109), Kautsky vincula a grande influência da filosofia schopenhaueriana à posição ideológica por ela representada, atacando o pensamento de Schopenhauer ao fazer apelo à biografia do autor: filósofo representante da pequena burguesia rentista, cunhado ainda com o espírito da Santa Aliança e adversário político declarado das revoltas de 1848. Essa interpretação político-biográfica acaba por resumir o pessimismo schopenhaueriano à expressão ideológica de uma burguesia acomodada (que se identifica com o papel do gênio e seus privilégios na filosofia schopenhaueriana) e cujo caráter quietista ajudaria a fortalecer o conformismo na classe proletária (que, por sua vez, poderia se identificar com o papel do santo e sua resignação). Por isso, conclui Kautsky, "não é nenhuma surpresa que essa doutrina tão comodista alastre-se rapidamente e adquira sempre novos adeptos" (KAUTSKY, 1888, p. 109). Portanto, a crítica de Kautsky pode ser inserida no mesmo conjunto daquelas interpretações histórico-ideológicas mencionadas acima.
} 
manifestação psicológica, extrafilosófica. Estratégias críticas semelhantes foram adotadas pelos neokantianos Riehl, Liebmann, Paulsen e Bona Meyer. ${ }^{30}$

Historiadores da filosofia ressaltam outros aspectos importantes que permeiam as críticas neokantianas. Beiser, por exemplo, chama a atenção para um pressuposto central dessas críticas: os neokantianos voltaram-se diretamente contra a concepção schopenhaueriana da filosofia como metafísica (BEISER, 2016, p. 25). Semelhantemente, Köhnke afirma que o ataque ao suposto estatuto científico do pessimismo ilustra como os neokantianos estabeleciam uma distinção rígida entre filosofia e Weltanschauung, insistindo no caráter científico da filosofia (KÖHNKE, 1991, p. 217-218). Em defesa de Schopenhauer, podemos dizer que uma parte substancial das críticas neokantianas à pretensão científica do pessimismo fora motivada mais pela versão hartmanniana do pessimismo do que pela própria letra de Schopenhauer. Afinal, mesmo que Schopenhauer realmente confira valor de verdade ao juízo negativo sobre o valor da vida, a insistência (marcada por exigências típicas da segunda metade do século XIX, como já mencionamos) em atribuir um estatuto científico ao pessimismo aparece sobretudo na obra de Hartmann. ${ }^{31}$

Além das críticas à fundamentação do pessimismo, alguns neokantianos dedicaram-se também a criticar elementos específicos do sistema schopenhaueriano. Kuno Fischer e Bona Meyer, por exemplo, atacam a soteriologia. ${ }^{32}$ Riehl critica, por um lado, a concepção (segundo ele, operada por Schopenhauer) do mundo como um "fenômeno cerebral" como uma deturpação do verdadeiro criticismo kantiano e, por outro lado, a própria noção schopenhaueriana de vontade, que seria apenas uma "antropomorfização da

\footnotetext{
${ }^{30}$ Riehl também defende haver um contrassenso por trás da "questão do valor da vida, do valor da existência em geral, colocada por Schopenhauer": "O valor da existência, o valor do mundo pode ser avaliado? A medida para essa avaliação não deveria ser tirada do próprio mundo, da própria vida que, conforme isso, deve ser avaliada? Um juízo de valor pressupõe a possibilidade de uma comparação. Como, porém, o ser, que é tudo, pode ser comparado, como seu valor pode ser avaliado já que todo valor e todo não-valor está contido nele e dele provem" (RIEHL, 1908, p. 213). Já Liebmann afirma: é uma "confusão conceitual" querer julgar a questão do valor da existência em geral. "Valor e não-valor" seriam "predicados totalmente relativos" ao "sujeito julgador" (LIEBMANN, 1904, p. 264-265), e portanto: "Que absurdo querer julgar o valor do mundo em geral [...] Bom e mau, como belo e feio, são conceitos de valor subjetivos, [...] nunca, porém, aplicáveis àquela infinita e impenetrável essência do mundo" (LIEBMANN, 1904, p. 266). Paulsen, num texto publicado primeiramente em 1900, amplia de certa forma o argumento, recorrendo a aspectos biográficos de Schopenhauer para reforçar a acusação de subjetivismo e psicologismo: a "solidão" do filósofo teria feito com que ele perdesse o principal, a arte de "se justificar diante dos outros; ele ouve apenas a si mesmo e gira progressivamente em torno de seus pensamentos como num mundo onírico, sem mais diferenciar elementos subjetivos e objetivos" (PAULSEN, 1911, p. 53). Bona Meyer também foca sua crítica na redução do pessimismo a um psicologismo: o pessimismo "nada mais é senão o testemunho de um doentio temperamento negro amargo" (BONA MEYER, $1872 \mathrm{a}$, p. 44).

${ }^{31}$ Num artigo denominado Ist der Pessimismus wissenschaftlich zu begünden? [O pessimismo deve se fundamentar cientificamente?], por exemplo, assevera Hartmann: "Pode-se afirmar que o pessimismo hoje já pertence a uma das verdades cientificamente mais bem fundamentadas e que sua certeza crescerá tanto com o avanço do curso real do mundo quanto com o avanço de seu tratamento científico, hoje ainda tão recente" (HARTMANN, 1880, p. 85).

32 Fischer critica a filosofia schopenhaueriana por atribuir papel central ao intelecto na negação da vontade e na metafísica do belo: "não é possível" "nem lógica nem metafisicamente" que o intelecto, "escravo nato da vontade" tenha esse papel redentor (FISCHER, 1898, p. 514). Bona Meyer vê na negação da vontade "uma evidente contradição de sua doutrina [...] essa autonegação da própria essência é totalmente impossível” (BONA MEYER, 1872a, p. 45).
} 
natureza", um "mito filosófico" (RIEHL, 1908, p. 217-220). ${ }^{33}$ Mencionemos também a famosa crítica do neokantiano Eduard Zeller à suposta petição de princípio entre cérebro e representação na teoria do conhecimento schopenhaueriana, conhecida tradicionalmente na historiografia filosófica como paradoxo de Zeller. ${ }^{34}$ Outra crítica efetuada frequentemente pelos neokantianos ao pessimismo diz respeito à possibilidade de determinar um balanço entre prazer e desprazer na existência. Riehl e Bona Meyer, por exemplo, enfatizam esse aspecto. ${ }^{35}$ Aqui novamente devemos observar que esse aspecto da crítica neokantiana é facilitado pela insistência de Hartmann em fundamentar o pessimismo filosófico a partir de um balanço eudemonista, ${ }^{36}$ algo que não ocorre da mesma maneira na letra schopenhaueriana.

Outro ponto central da crítica dos neokantianos ao pessimismo schopenhaueriano tem um fundamento político. Segundo seus opositores, o pessimismo de Schopenhauer traria consigo uma apologia do quietismo, desestimulando a ação política e propagando uma ideologia conservadora do status quo. Segundo Riehl, a doutrina schopenhaueriana "nega a vida, ela quer negá-la, e sua crença paralisa a ação" (RIEHL, 1908, p. 215). Noutras palavras: "para poder afirmar o pessimismo, Schopenhauer teve de negar a história [...] Ele recusa em si e incondicionalmente a possibilidade de qualquer melhoria, e por isso sua doutrina é inimiga da vida" (Idem, p. 214-215). Liebmann também insistira nessa crítica, afirmando que o quietismo schopenhaueriano "cruza os braços" diante da possibilidade de "melhorar o mundo", e concluindo em tom exortativo: "em vez de pronunciar reclamações estéreis contra a ordem eterna do mundo, que tu não compreendes, ajas! Combata o mal, fomente o bem; ajude os doentes, pobres, fracos, sofredores; recuse a injustiça e a maldade" (LIEBMANN, 1904, p. 262-266). Como contrapartida a essa crítica, podemos argumentar que o pessimismo schopenhaueriano, por si só, não implica necessariamente uma ideologia reacionária. Prova disso (para ficarmos restritos ao período abordado, pois poderíamos relembrar a importância da filosofia schopenhaueriana para Max Horkheimer, por exemplo) é o viés socialista presente na filosofia de um dos principais representantes da escola de Schopenhauer, Mainländer, definido por Ramos como "um pessimismo quietista com práxis social engajada" (RAMOS, 2007, p. 44).

Essa crítica de cunho político nos leva à última faceta dos ataques neokantianos ao pessimismo de Schopenhauer que abordaremos aqui: além do viés político, inegavelmente pairava sobre essa corrente crítica um componente

33 "O mundo é um fenômeno cerebral para um cérebro que é seu próprio fenômeno - isso não é criticismo, isso é ilusionismo, é niilismo do conhecimento e uma completa distorção da doutrina kantiana. E, entretanto, a falsa concepção de Schopenhauer sobre Kant encobre ainda para muitos o verdadeiro sentido da filosofia crítica" (RIEHL, 1908, p. 217). Sobre a vontade: "o metafísico da vontade compreendeu mal a vontade; Schopenhauer não conhece a vontade, ele a confunde com o desejo" (Idem, p. 219).

${ }^{34}$ Zeller formula essa crítica em sua Geschichte der deutschen Philosophie seit Leibniz [História da filosofia alemã desde Leibniz] (ZELLER, 1875, p. 713).

${ }^{35}$ Afirma Riehl: "O pessimismo schopenhaueriano é, em seu fundamento, hedonista", pois se baseia na "contabilização do balanço entre prazer e sofrimento" (RIEHL, 1908, p. 232). Já Bona Meyer: "A questão de se no mundo existe mais prazer ou desprazer não é decidível com a ajuda de nenhuma experiência [...] tal balanço de prazer e desprazer [...] é uma tarefa impossível" (BONA MEYER, 1872a, p. 44-45).

36 Ver, por exemplo, HARTMANN, 1885, p. 91-102. 
pessoal. A constante intromissão de argumentos ad hominem nas críticas supramencionadas já permite antever esse aspecto. Como dissemos, o neokantismo tornou-se a corrente filosófica hegemônica na academia filosófica alemã durante a segunda metade do século XIX. Schopenhauer, crítico por excelência da filosofia universitária, representava em vários aspectos uma ameaça ao movimento neokantiano. Em Sobre a filosofia universitária Schopenhauer já atacara diretamente pioneiros do neokantismo, como Jakob Fries (SCHOPENHAUER, P I, p. 224). Além disso, o filósofo elogiara a cassação da jus legendi de um dos principais neokantianos da segunda metade do século XIX: Kuno Fischer (SCHOPENHAUER, P I, p. 176). Não por acaso, Fischer é um dos principais críticos da postura schopenhaueriana contra a filosofia acadêmica. Valendo-se da correspondência de Schopenhauer publicada, Fischer acusa o filósofo de se alegrar ao saber da destituição de acadêmicos, alegando que essa posição não era motivada por razões intelectuais, mas pessoais (FISCHER, 1898, p. 98-99). O neokantiano ironiza ainda o modo como Schopenhauer interpretava seu período de anonimato: o "velho conto de fadas. Para não deixar que ele, o único verdadeiro herdeiro do trono de Kant, chegasse ao poder, professores de filosofia conspiraram e segregaram-no dos olhos do mundo" (FISCHER, 1898, p. 492). Avançando em argumentos ad hominem (estratégia crítica que, devemos reconhecer, não era estranha ao próprio Schopenhauer), conclui Fischer: o próprio Schopenhauer "foi um professor universitário, um João sem terra, um professor sem ouvintes", eis por que sua crítica à filosofia universitária tinha por fundamento "sua amargura" (FISCHER, 1898, p. 493-494). Paulsen acompanha a ironia de Fischer ao insinuar um caráter paranoico de Schopenhauer em relação aos professores de filosofia ${ }^{37}$. Além disso, tanto Paulsen quanto outro neokantiano, Haym, alegam que o ambiente acadêmico teria sido benéfico para Schopenhauer, pois forçaria o filósofo misantropo a justificar sua filosofia perante colegas e alunos. ${ }^{38}$

Em última instância, os ataques neokantianos a Schopenhauer durante a Pessimismus-Frage foram tão inflamados porque o objeto da controvérsia não se restringia apenas ao estatuto teórico do pessimismo filosófico: tais ataques eram atravessados também por interpretações políticas ou mesmo querelas pessoais. Contudo, ao privilegiarmos o aspecto propriamente filosófico da questão, devemos enfatizar que (mesmo que outros elementos permeiem o debate) o objeto principal da controvérsia e seu verdadeiro pano de fundo era nada menos que a concepção de filosofia. Vejamos por quê.

Com a proliferação das críticas ao pessimismo e a Schopenhauer, bem como das réplicas por parte dos defensores do pessimismo filosófico (dentre eles Taubert, Plümacher e, sobretudo, Hartmann) ${ }^{39}$, a Pessimismus-Frage alastrou-se

\footnotetext{
37 Referindo-se ao suposto "plano" orquestrado pelos acadêmicos das gerações anteriores para manter Schopenhauer no anonimato, afirma Paulsen: "é indubitável que esse feitiço é um puro fantasma de sua fantasia [...] Voltemos àquela época e levemos a sério a ideia: Hegel e Fries, Herbart e Schelling, Baader e Reinhold, [...] reuniram-se e conspiraram contra a fama - não do famoso Arthur Schopenhauer, mas de um jovem desconhecido que se habilitou em Berlim, porém teve pouco sucesso [...] Como se cada um deles não tivesse coisas muito mais importantes a fazer do que estudar a obra de um desconhecido de nome Schopenhauer!" (PAULSEN, 1911, p. 48-49).

${ }^{38}$ Ver PAULSEN, 1911, p. 32, e HAYM, 1864, p. 87-88.

39 Ao mesmo tempo em que funcionava como potencializador dessas críticas devido à sua peculiar reformulação do pessimismo schopenhaueriano, Hartmann era geralmente o protagonista da contra-argumentação pessimista. O filósofo dedicou obras inteiras - como Zur Geschichte und Begründung des Pessimismus (HARTMANN, 1880), que teve uma segunda edição, ampliada, em
} 
intensivamente durante as décadas finais do século XIX. Segundo Beiser, foi "a maior controvérsia intelectual - mensurada em termos de duração, intensidade e número de participantes - na segunda metade do século XIX na Alemanha" (BEISER, 2016, p. 162). Mas por que justamente a questão do pessimismo, introduzida no debate filosófico com a difusão do pensamento schopenhaueriano, tornou-se importante a ponto de originar uma polêmica dessa magnitude? Lembremos daquela descrição inicial do cenário intelectual alemão da segunda metade do século XIX. Tal cenário tinha como características marcantes o descrédito em relação aos sistemas idealistas especulativos que dominaram a primeira metade do século, culminando numa desconfiança acerca do próprio papel da filosofia, sobretudo da metafísica e da ética, bem como numa concomitante valorização crescente das ciências particulares. Usamos as palavras de Schnädelbach para descrever essa conjuntura como uma "crise de identidade da filosofia” (SCHNÄDELBACH, 1983, p. 17). Nesse panorama, o neokantismo erigiu-se como corrente filosófica dominante na filosofia universitária, oferecendo como saída para essa crise uma concepção da filosofia como teoria do conhecimento, cujo papel seria investigar e estabelecer os fundamentos das ciências, recusando especulações metafísicas e Weltanschauungen de maneira geral. Ora, é evidente que a concepção de filosofia oferecida por Schopenhauer entra em confronto direto com essa concepção neokantiana.

Além de apresentar uma concepção tipicamente metafísica, é crucial perceber o que uma Weltanschauung pessimista pressupõe. A questão do pessimismo mostra-se inserida num horizonte maior, que pressupõe uma tomada de posição acerca da própria natureza e dos limites da filosofia. Afinal, defender o pessimismo filosófico significa a fortiori trazer para o primeiro plano uma questão filosófica fundamental: a questão do valor da vida ou da existência. O pessimismo pressupõe uma concepção determinada da filosofia, a saber, ele assume a questão do valor da vida como a questão filosófica por excelência. Schopenhauer tinha plena consciência dessa condição. Na abertura do livro IV do primeiro volume d' $O$ mundo como vontade e representação, o filósofo afirma que nele tratará da questão "mais séria de todas, já que diz respeito às ações dos homens, ao tema com o qual cada um imediatamente lida, não podendo ser alheio ou indiferente a ninguém" (SCHOPENHAUER, WWV I, p. 375). Poucas linhas abaixo, Schopenhauer deixa claro qual é essa questão: "o valor ou não-valor de uma existência" (SCHOPENHAUER, WWV I, p. 375). Além disso, é interessante observar que essa concepção aparece no próprio escrito Sobre a filosofia universitária. Ao contrapor a concepção assumida pelos filósofos universitários à sua própria concepção da filosofia, afirma Schopenhauer: "eles nada sabem sobre abordar livre e naturalmente o problema da existência [Problem des Daseins]" (SCHOPENHAUER, P I, p. 233) que, segundo o filósofo de Danzig, é "incomparavelmente o problema mais importante de todos" (Idem, p. 222). Assim, fica claro por que o pessimismo tornou-se um objeto de disputa tão importante neste cenário. Em torno da questão do pessimismo digladiavam-se concepções antagônicas da filosofia: a neokantiana, concebendo como papel central da filosofia a investigação acerca dos fundamentos das ciências particulares, e a schopenhaueriana, que concebia como problema filosófico central a questão do valor da existência. Em última instância, o principal

1892 -, além de artigos como Zur Pessimismus-Frage (HARTMANN, 1885, p. 78-120), à tentativa de refutar as críticas ao pessimismo filosófico. 
sustentáculo da enorme influência do pensamento de Schopenhauer no cenário intelectual alemão do período - segundo Köhnke, numa obra dedicada ao movimento neokantiano, a filosofia schopenhaueriana foi o "maior sucesso popular do século XIX" (KÖHNKE, 1991, p. 74) ${ }^{40}$ - foi trazer novamente à tona essa antiga (porém, à época desacreditada) questão e situá-la no centro de sua concepção filosófica. Mesmo um neokantiano reconhece, a seu modo, esse feito: "sob a influência de Schopenhauer cultivou-se uma verdadeira mania de julgar o "valor da vida" (WINDELBAND, 1924, p. 226). Dentre os historiadores da filosofia, Beiser ratifica essa interpretação. ${ }^{41}$ Porém, talvez a melhor compreensão desse mérito schopenhaueriano tenha nos sido fornecida por ninguém menos que Nietzsche. Primeiramente numa obra de juventude, Schopenhauer como educador, Nietzsche atribui a Schopenhauer o papel de educador principalmente devido àquela concepção da filosofia. Vale a pena atentar às palavras nietzschianas:

\begin{abstract}
Ele havia visto algo ainda superior: uma terrível cena supramundana do julgamento, em que era pesada toda vida, mesmo a mais alta e perfeita, e considerada leve demais: tinha visto o sagrado como juiz da existência [Richter des Daseins]. Não é possível determinar o quão cedo Schopenhauer deve ter visto essa imagem da vida, e aliás precisamente assim como tentou pintá-la mais tarde em todos os seus escritos; pode-se demonstrar que o jovem, e desejaríamos acreditar que a criança, já havia tido essa visão descomunal. Tudo de que ele se apropriou mais tarde, da vida e dos livros, de todos os reinos da ciência, era para ele quase que somente cor e meio de expressão; mesmo a filosofia de Kant foi adotada por ele, antes de tudo, como um extraordinário instrumento retórico, com que acreditava pronunciar-se ainda mais claramente sobre essa imagem: como também lhe servia para o mesmo fim, ocasionalmente, a mitologia budista e cristã. Para ele havia somente uma tarefa e cem mil meios para resolvê-la: um sentido e inúmeros hieróglifos para exprimi-lo. (NIETZSCHE, 1978, p. 78-79; grifos do autor).
\end{abstract}

Nietzsche explicitamente adere à concepção schopenhaueriana da filosofia: a "exigência de toda grande filosofia [...] sempre diz unicamente: esta é a imagem de toda vida, aprende nela o sentido da tua vida [Sinn deines Lebens]. E vice-versa: lê apenas tua vida e aprende nela os hieróglifos da vida universal" (NIETZSCHE, 1999, Band 1, p. 357). Portanto, também para o jovem Nietzsche ao verdadeiro filósofo é atribuído sobretudo o papel de "juiz da vida" (NIETZSCHE, 1999, Band 1, p. 362), e a verdadeira filosofia deve ter como questão principal o "problema da existência" [Problem des Daseins] (Idem, p. 365). Mesmo após seu afastamento em relação a Schopenhauer (que sempre deve ser considerado em seus multifacetados aspectos, pois não se trata de uma simples ou unidimensional ruptura), Nietzsche não apenas continua a reconhecer o grande mérito de Schopenhauer ao ter implementado essa concepção da filosofia em seu tempo, como também especifica

\footnotetext{
${ }^{40}$ Embora possa, à primeira vista, parecer peremptória, essa afirmação é endossada totalmente por um autor da época: "a filosofia de Schopenhauer e seus sucessores" foi, segundo Wundt, "mais popular como nunca dantes fora a filosofia na Alemanha" (WUNDT, 1877, p. 505).

${ }^{41}$ Beiser atesta "a grande importância de Schopenhauer para a reorientação da filosofia na segunda metade do século XIX. Foi Schopenhauer quem fez a questão do valor da vida tão central na filosofa alemã no século XIX, que afastou seus interesses pela lógica das ciências e trouxe-os de volta aos problemas tradicionais da significação e valor da vida” (BEISER, 2016, p. 11).
} 
a originalidade desse mérito. No livro $\mathrm{V}$ d’ $A$ gaia ciência (portanto, já ao final de sua trajetória intelectual), Nietzsche afirmará que "Schopenhauer, com o seu pessimismo, ou seja, com o problema do valor da existência" (NIETZSCHE, 2005, p. 255; grifos do autor), teve o mérito inquestionável de ter sido o "primeiro ateísta confesso e inabalável que nós, alemães, tivemos [...] Toda a sua retidão está nisso; o ateísmo incondicional e honesto é o pressuposto de sua colocação dos problemas" (Idem, pp. 255-256; grifos do autor). Segundo Nietzsche, Schopenhauer é pessimista "como bom europeu", pois o problema fundamental de sua filosofia foi um problema a se "esperar com total certeza" após o grande "evento de toda a Europa", a "vitória obtida afinal e com grande custo pela consciência europeia": "o declínio da crença no Deus cristão" (Idem, Ibidem). Conforme a interpretação nietzschiana, a concepção filosófica schopenhaueriana é tão importante porque teve o mérito de colocar, pela primeira vez e de maneira clara, a questão crucial de seu tempo:

Ao assim rejeitarmos a interpretação cristã e condenarmos o seu 'sentido' como uma falsificação, aparece-nos de forma terrível a questão de Schopenhauer: então a existência tem algum sentido? - essa questão que precisará de alguns séculos para simplesmente ser ouvida por inteiro e em toda a sua profundidade. (Idem, p. 256; grifos do autor).

Nietzsche ressalta ainda a superioridade do pessimismo schopenhaueriano face à "inabilidade desse pessimismo pós-schopenhaueriano" (Idem, p. 257: "grifos do autor"), citando nominalmente e satirizando cada um dos três representantes da escola de Schopenhauer em sentido lato que apresentamos acima: Bahnsen, Mainländer e Hartmann. Enfim, esse recurso a Nietzsche nos ajuda a entender não apenas por que a filosofia schopenhaueriana tornou-se a mais influente e mais debatida na Alemanha durante o período da Pessimismus-Frage quanto por que, em última instância, podemos dizer que Schopenhauer foi o grande vitorioso dessa controvérsia.

É compreensível a indagação de Beiser: "de uma perspectiva contemporânea, é um fato surpreendente, difícil de avaliar e explicar, que Arthur Schopenhauer foi o mais famoso e influente filósofo na Alemanha de 1860 até a Primeira Guerra Mundial" (BEISER, 2016, p. 13). Contudo, se atentarmos ao panorama da Pessimismus-Frage apresentado, esse fato torna-se menos surpreendente. Afinal, como procuramos mostrar até aqui, após a morte de Schopenhauer a controvérsia pessimista que se alastrou pela Alemanha acabava por, de forma indireta, ratificar aquela concepção schopenhaueriana da filosofia. Seja quando defendida pelos partidários do pessimismo filosófico, ou mesmo quando criticada em sua legitimidade pelos opositores, a questão do valor da vida transformou-se na questão central do debate da filosofia alemã no período. Um significado histórico importante da Pessimismus-Frage foi, sem dúvida, deslocar o horizonte discursivo da filosofia alemã em direção à concepção filosófica schopenhaueriana. Dessa perspectiva, não surpreende que Schopenhauer tenha sido, de fato, o mais influente filósofo alemão do período. Afinal, segundo as próprias palavras de Beiser: "num sentido muito importante, Schopenhauer pautou a agenda intelectual da segunda metade do século XIX. Ele [...] colocou o problema filosófico principal de sua época" (BEISER, 2016, p. 15). 
Além disso, é preciso ainda considerar outro fator. Se a filosofia schopenhaueriana tornou-se tão influente e popular nesse período é também porque, de alguma forma, ela conseguiu fornecer uma resposta mais convincente à "crise de identidade" que atravessava a filosofia alemã. ${ }^{42}$ Eis um dos motivos pelos quais podemos afirmar que a filosofia schopenhaueriana sagrou-se vencedora da Pessimismus-Frage. Outro motivo, complementar a esse, é a constatação de que a influência da concepção schopenhaueriana da filosofia chegou a tal ponto que seus principais críticos, os neokantianos, viram-se a partir de certo momento forçados a ampliar sua própria concepção, passando a incorporar - ao lado dos tradicionais temas relativos à teoria do conhecimento questões de valor entre seus temas filosóficos. ${ }^{43}$

Portanto, essa apresentação panorâmica da Pessimismus-Frage pretende ter ajudado a dimensionar a relevância, muitas vezes subestimada, de Schopenhauer para a filosofia alemã do final do século XIX. Como conclusão, podemos justificadamente afirmar que, de certo modo, a filosofia schopenhaueriana delimitou grande parte do horizonte em torno do qual orbitou a filosofia alemã neste período. Rememorando esse importante (e geralmente esquecido) episódio da história da filosofia, pretendemos também prestar homenagem ao misantropo de Frankfurt por ocasião do bicentenário da publicação de sua obra magna.

\section{REFERÊNCIAS BIBLIOGRÁFICAS}

ASHER, David. Eine neue Weltanschauung. Allgemeine Zeitung, p. 2278-2279, 28/5/1869.

BAHNSEN, Julius. Zur Philosophie der Geschichte: Eine kritische Besprechung des Hegel-Hartmann'schen Evolutionismus aus Schopenhauer'schen Principien. Berlin: Duncker, 1872.

\footnotetext{
${ }^{42}$ Nisso acompanhamos a conclusão à qual chega Beiser: "A filosofia de Schopenhauer tornou-se tão influente principalmente porque ela ofereceu a mais bem-sucedida solução para aquela crise, uma solução mais plausível e satisfatória do que as de seus oponentes [...] Em última instância, para o público em geral a concepção de filosofia de Schopenhauer provou-se uma solução mais atrativa para a crise de identidade da filosofia do que a concepção neokantiana” (BEISER, 2016, p. 18-22).

${ }^{43}$ Essa é também uma das teses centrais da obra de Beiser. Originalmente estudioso do movimento neokantiano, ele fornece um relato interessante a esse respeito: "cheguei ao estudo do pessimismo por meio do neokantismo. Qualquer um que estude as origens do movimento neokantiano fica perplexo com a influência que Schopenhauer teve sobre o movimento" (BEISER, 2016, p. V). Segundo o autor, "Os neokantianos teriam provavelmente continuado a trilhar seu caminho positivista - eles provavelmente persistiriam em seu 'sono dogmático' - se não fosse por um homem: o velho scrooge de Frankfurt. Ninguém foi mais efetivo em despertar os neokantianos, em relembrá-los das questões tradicionais da filosofia, do que Arthur Schopenhauer" (Idem, p. 21). E complementa afirmando que a influência da filosofia schopenhaueriana acabou por repercutir até mesmo sobre a filosofia universitária: "Ao final da década de 1870, os neokantianos começaram a sentir o desafio de Schopenhauer, mesmo nas salas das universidades. A filosofia de Schopenhauer estava provando ser popular entre os estudantes, que se sentiam mais atraídos por preleções sobre o enigma da existência do que por sobre a lógica das ciências. Face ao declínio do interesse estudantil, e preocupados em ter alguma relevância social, os neokantianos começaram a ampliar sua concepção de filosofia para além da epistemologia, de modo que ela pudesse incluir o problema do valor [...] Começando ao final da década de 1870, houve um grande crescimento do número de preleções ministradas por neokantianos sobre tópicos de filosofia prática e sobre a natureza da filosofia" (BEISER, 2016, p. 23).
} 
Der Widerspruch im Wissen und Wesen der Welt: Princip und Einzelbewährung der Realdialektik. Leipzig: Grieben, 1882.

BEISER, Frederick C. Weltschmerz: Pessimism in German Philosophy, 1860-1900. New York: Oxford University Press, 2016.

BONA MEYER, Jürgen. Arthur Schopenhauer als Mensch und Denker. In: BIRCHOW, Rudolf; HOLZENDORFF, Franz. (Orgs). Sammlung gemeinverständlicher wissenschaftlicher Vorträge. Berlin: Carl Habel, 1872a. p. 154.

Eine Rede gegen Schopenhauer's und Hartmann's Pessimismus. Bonn: Adolph Marcus, 1872b.

CARTWRIGHT, David E. Schopenhauer: A Biography. Cambridge: Cambridge University Press, 2010.

CIRACI, Fabio; FAZIO, Domenico; KOßLER, Matthias. Schopenhauer und die Schopenhauer-Schule. Würzburg: Königshausen \& Neumann, 2009.

DURANTE, Felipe. A escola de Schopenhauer em seus sentidos lato e estrito: entre apóstolos, evangelistas, metafísicos, heréticos, os pais da Igreja e as mulheres. Revista Sofia, v. 6, n. 1, p. 136-148, Jan/Jun 2017.

FAZIO, Domenico. La scuola di Schopenhauer: testi e contesti. A cura del Centro interdipartimentale di ricerca su Arthur Schopenhauer e la sua scuola dell'Università del Salento. Lecce: Pensa Multimedia, 2009.

Nietzsche e il pessimismo post-schopenhaueriano: Hartmann, Mainländer e Bahnsen. La passione della conoscenza. Studi in onore di Sossio Giametta. A cura del Centro interdipartimentale di ricerca su Arthur Schopenhauer e la sua scuola dell'Università del Salento. Lecce: Pensa Multimedia, 2010. p. 161-184.

FISCHER, Kuno. Geschichte der neuern Philosophie. Neunter Band: Schopenhauers Leben, Werke und Lehre. Heidelberg: Karl Winter, 1898.

GOLTHER, Ludwig von. Der moderne Pessimismus. Leipzig: Brockhaus, 1878.

HARTMANN, Eduard von. Ueber die nothwendige Umbildung der Schopenhauerschen Philosophie aus ihrem Grundprincip heraus. Philosophische Monatshefte, Band II, Berlin, p. 457-469, Wintersemester 1868/1869.

. Philosophie des Unbewussten. Berlin: Duncker, 1869.

. Philosophie des Unbewussten. Siebente Auflage. Berlin: Duncker, 1876.

Zur Geschichte und Begründung des Pessimismus. Berlin: Duncker, 1880.

Philosophische Fragen der Gegenwart. Leipzig/Berlin: Verlag von Wilhelm Friedrich, 1885.

. Zur Geschichte und Begründung des Pessimismus. Zweite Auflage, Leipzig: Hermann Haacke, 1892.

HAYM, Rudolf. Arthur Schopenhauer. Berlin: Georg Reimer, 1864. 
HEYDORN, Heinz-Joachim. Schopenhauer und Bahnsen. Schopenhauer-Jahrbuch, n. XXXVII, p. 32-41, 1956.

INVERNIZZI, Giuseppe. Il pessimismo tedesco dell'ottocento: Schopenhauer, Hartmann, Bahnsen e Mainländer e i loro avversari. Firenze: La Nuova Italia Editrice, 1994.

KAUTSKY, Karl. Arthur Schopenhauer. Die neue Zeit, 6, p. 66-78 e 97-109, 1888.

KÖHNKE, Klaus Christian. The rise of neo-Kantianism: German academic philosophy between idealism and positivism. Cambridge: Cambridge University Press, 1991.

LIEBMANN, Otto. Gedanken und Thatsachen. Zweiter Band. Strassburg: Karl Trübner, 1904.

LUKÁCS, Georg. Die Zerstörung der Vernunft: Irrationalismus und Imperialismus. Band II. Darmstadt und Neuwied: Hermann Luchterland, 1974.

MAINLÄNDER, Philipp. Die Philosophie der Erlösung. Berlin: Theodor Hofmann, 1879 .

NIETZSCHE, Friedrich. Nietzsche: Obras incompletas. Col. Os pensadores. Tradução de Rubens Rodrigues Torres Filho. São Paulo: Abril Cultural, 1978.

Kritische Studienausgabe (KSA) em 15 volumes (org. Colli-Montinari). München: Walter de Gruyter, 1999.

A gaia ciência. Tradução de Paulo César de Souza. São Paulo: Companhia das Letras, 2005.

PAUEN, Michael. Pessimismus: Geschichtsphilosophie, Metaphysik und Moderne von Nietzsche bis Spengler. Berlin: Akademie Verlag, 1997.

PAULSEN, Friedrich. Schopenhauer, Hamlet und Mephistopheles. Dritte Auflage. Stuttgart/Berlin: Gotta'sche, 1911.

PFEIDERER, Edmund. Der moderne Pessimismus. Berlin: Carl Habel, 1875.

PLÜMACHER, Olga. Der Pessimismus in Vergangenheit und Gegenwart. Heidelberg: G. Weiss, 1888.

RAMOS, Flamarion Caldeira. O pessimismo e a questão social em Philipp Mainländer. Cadernos de Filosofia Alemã (USP), n. 10, p. 35-50, 2007.

Tragédia sem redenção: o pessimismo absoluto de Julius Bahnsen. Revista Voluntas: Estudos sobre Schopenhauer, v. 6, n. 2, p. 111-121, 2o semestre de 2015.

RIEHL, Alois. Zur Einführung in die Philosophie der Gegenwart. Dritte Auflage. Leipzig: B.G Teubner, 1908.

SCHNÄDELBACH, Herbert. Philosophie in Deutschland: 1831-1933. Frankfurt am Main: Suhrkamp, 1983.

SCHOPENHAUER, Arthur. Sämtliche Werke (org. Löhneysen) em 5 volumes. Stuttgart/Frankfurt am Main: Suhrkamp, 1986. 
STÄGLICH, Hans. Zur Geschichte des Begriffs Pessimismus. SchopenhauerJahrbuch, n. XXXIV, p. 27-37, 1951-1952.

SUlLY, James. Pessimism: A History and a Criticism. London: Henry S. King, 1877.

TAUBERT, Agnes. Der Pessimismus und seine Gegner. Berlin: Duncker, 1873.

VITALE, Maria. Dalla Volontà di vivere all'Inconscio: Eduard von Hartmann e la transformazione della filosofia di Schopenhauer. A cura del Centro interdipartimentale di ricerca su Arthur Schopenhauer e la sua scuola dell'Università del Salento (Schopenhaueriana, 8). Lecce: Pensa Multimedia, 2014.

WINDELBAND, Wilhelm. Pessimismus und Wissenschaft. Präludien, Band I/II. Tübingen: Mohr, 1924.

WOLF, Jean-Claude. Eduard von Hartmann: Ein Philosoph der Gründerzeit. Würzburg: Königshausen \& Neumann, 2006.

WUNDT, Wilhelm. Philosophy in Germany. Mind, Oxford University Press, vol. 2, no 8 , p. 493-518, 1877.

ZELLER, Eduard. Geschichte der deutschen Philosophie seit Leibniz. Zweite Auflage. München: R. Oldenbourg, 1875.

Recebido em: 31-07-2018

Aceito para publicação em: 02-11-18 